\title{
Phenolic profile, antioxidant and antifungal activity of extracts from four medicinal plants of the Anacardiaceae family
}

Perfil fenólico, atividade antioxidante e antifúngica de extratos de quatro plantas medicinais da família Anacardiaceae

Perfil fenólico, actividad antioxidante y antifúngica de extractos de cuatro plantas medicinales de la familia Anacardiaceae

\begin{abstract}
The aim of this study was to evaluate the chemical profile and the antioxidant and antifungal activities of the ethanol extracts of four Anacardiaceae species, also including the computational study of the mechanism of action of phenolic compounds against the Trichophyton rubrum aspartate semialdehyde dehydrogenase enzyme. For this, the contents of phenols and flavonoids in the extracts were determined. The antifungal activity of the extracts was evaluated by microdilution in broth on T. rubrum fungi and the antioxidant capacity was analyzed by measuring the scavenging effect of the extracts against the 2,2'-diphenyl-1-picrylhydrazyl (DPPH) radical. For the study of molecular docking, computer simulations of the interaction between enzyme and ligands were performed using the AutoDock Vina Code. The phenolic and flavonoid contents ranged from $227.47 \pm 18.62$ to $493.44 \pm 13.89$ gallic acid equivalent (EAG), $14.86 \pm 0.22$ to $86.07 \pm 1.67$ quercetin equivalent $(\mathrm{EQ})$, respectively. Antioxidant activity ranged from $3.73 \pm 0.12$ to $11.21 \pm 0.49 \mu \mathrm{g} / \mathrm{mL}$, especially for Spondias mombim. The ethanol extracts showed antifungal activity against most strains of T. rubrum. The compounds rutin, ellagic acid, quercetin, isoquercitrin and mangiferin present in the species, showed higher affinity for the enzyme aspartate semialdehyde dehydrogenase in relation to fluconazole, the antifungal standard. These results provide evidence that the ethanol extracts of Anacardiaceae can be potential sources of new biotechnological products, acting as natural antioxidant and antifungal agents.
\end{abstract}

Keywords: Biological activities; Plant species; Cocó State Park; Free radicals. 


\begin{abstract}
Resumo
O objetivo deste estudo foi avaliar o perfil químico e as atividades antioxidante, e antifúngica dos extratos etanólicos de quatro espécies de Anacardiaceae, incluindo também o estudo computacional do mecanismo de ação de compostos fenólicos contra a enzima aspartate semialdehyde dehydrogenase de Trichophyton rubrum. Para isso foi determinado os teores de fenóis e flavonoides nos extratos. A atividade antifúngica dos extratos foi avaliada por microdiluição em caldo sobre os fungos T. rubrum e a capacidade antioxidante foi analisada medindo o efeito de eliminação dos extratos frente ao radical 2,2'-difenil-1-picrilhidrazil (DPPH). Para o estudo de docking molecular, simulações de computador de interação entre a enzima e ligantes foram realizadas usando o Código AutoDock Vina. Os conteúdos de fenólicos e flavonoides variaram de $227.47 \pm 18.62$ a $493.44 \pm 13.89$ equivalente de ácido gálico (EAG), $14.86 \pm$ 0.22 a $86.07 \pm 1.67$ equivalente de quercetina (EQ), respectivamente. Atividade antioxidante variou de 3,73 \pm 0.12 a $11.21 \pm 0.49 \mu \mathrm{g} / \mathrm{mL}$, com destaque para Spondias mombim. Os extratos etanólicos apresentaram atividade antifúngica contra a maioria das cepas de T. rubrum. Os compostos, ácido gálico, rutina, ácido elágico, quercetina, isoquercitrina e mangiferina presentes nas espécies, apresentaram uma mais alta afinidade pela enzima aspartate semialdehyde dehydrogenase, do que o fluconazol, antifúngico padrão. Esses resultados fornecem evidências de que os extratos etanólicos de Anacardiaceae podem ser fontes potenciais de novos produtos biotecnológicos, atuando como agentes antioxidantes e antifúngicos naturais.
\end{abstract}

Palavras-chave: Atividades biológicas; Espécies vegetais; Parque Estadual do Cocó; Radicais livres.

\title{
Resumen
}

El objetivo de este estudio fue evaluar el perfil químico y las actividades antioxidantes y antifúngicas de los extractos etanólicos de cuatro especies de Anacardiaceae, incluyendo también el estudio computacional del mecanismo de acción de los compuestos fenólicos contra la enzima espartato de Trichophyton rubrum semialdehído deshidrogenas aspartate. Para ello, se determinó el contenido de fenoles y flavonoides en los extractos. La actividad antifúngica de los extractos se evaluó mediante microdilución en caldo sobre hongos T. rubrum y la capacidad antioxidante se analizó midiendo el efecto eliminador de los extractos contra el radical 2,2'-difenil-1-picrilhidrazilo (DPPH). Para el estudio del acoplamiento molecular, se realizaron simulaciones por computadora de la interacción entre la enzima y los ligandos utilizando el AutoDock Vina Code. Los contenidos fenólicos y flavonoides variaron de 227,47 $\pm 18,62$ a 493,44 \pm 13,89 equivalente de ácido gálico (EAG), 14,86 \pm 0,22 a 86,07 \pm 1,67 equivalente de quercetina (EQ), respectivamente. La actividad antioxidante osciló entre 3,73 $\pm 0,12$ y 11,21 $\pm 0,49 \mu \mathrm{g} / \mathrm{ml}$, especialmente para Spondias mombim. Los extractos de etanol mostraron actividad antifúngica contra la mayoría de las cepas de $T$. rubrum. Los compuestos rutina, ácido elágico, quercetina, isoquercitrina y mangiferina, presentes en la especie, mostraran una mayor afinidad por la enzima aspartato semialdehído deshidrogenasa que el fluconazol, el antifúngico padron. Estos resultados proporcionan evidencia de que los extractos etanólicos de Anacardiaceae pueden ser fuentes potenciales de nuevos productos biotecnológicos, actuando como agentes antioxidantes y antifúngicos naturales.

Palabras clave: Actividades biológica; Especies vegetales; Parque Estatal Cocó; Radicales libres.

\section{Introduction}

Dermatophytoses are among the most recurrent human infections in the world, and a variety of antifungal drugs are used to treat this condition. However, these infections are becoming increasingly resistant to the different existing treatments, especially when they are caused by species of Microsporum and Trichophyton (Akroum, 2018). Given this problem, the development of new safe antifungal agents for the management of these pathogens represents not only an obstacle, but also an urgent need for new drugs (Espino et al., 2019).

Oxidative stress is a biological condition that leads to the formation of free radicals. These molecules are extremely harmful to living organisms, and thus have received greater attention due to their undesirable effects on health. To combat the harmful actions of free radicals, antioxidants are useful tools in reducing the risk of some chronic and acute diseases associated with the redox state of the human body. In this context, studies with medicinal plants are gaining more and more importance in the pharmaceutical, food and cosmetic industries, since the antioxidant properties of plant extracts have been attributed to their phenolic content (Bardacki et al., 2019; Penido et al., 2017).

Natural compounds derived from plants provide a promising research possibility, representing an alternative to synthetic drugs, due to their significant pharmacological and toxicological properties. In addition, natural products are considered potential new drugs against drug-resistant pathogens, among other conditions in the treatment of inflammatory and tumoral diseases (Ziani et al., 2020). Bioactive compounds present in plants, particularly in their extracts, are mainly secondary 
metabolites. Among them, phenolic compounds and alkaloids are the most relevant groups. In addition, these compounds have been reported for their therapeutic activities acting as antimicrobial, anti-inflammatory, antifungal and cardioprotective (Nascimento et al., 2021; Espino et al., 2019; Rodrigues et al., 2019; Sales et al., 2021).

Brazil is one of the countries with the huge biodiversity of plants existing in different biomes, and that these plants can present therapeutic potential. However, several plants from the phytogeographic domain present in Northeastern Brazil have been well investigated, regarding their pharmacological properties, although studies have shown that plants in this region are a rich source of biotechnological compounds (Luna et al., 2020; Araújo et al., 2014). The Cocó State Park, located in the city of Fortaleza-CE, occupies an environmental preservation area of 1,571.29 hectares. Its flora consists mostly of mangroves, also including decorative and medicinal plants as the representative species of the Anacardiaceae family (Morais et al., 2021).

This family is represented by about 75 genera and more than 700 species distributed in tropical and subtropical regions of the world, which is composed of species of trees or shrubs, used as ornamentals and also for medicinal purposes (Madikizela, Aderogba, Van Staden, 2013). Among the species of Anacardiaceae, Anacardium occidentale L., popularly known as cashew tree, Schinopsis brasiliensis Engl., whose popular name is baraúna, Spondias mombin L. popularly known as cajá, and Mangifera indica L. (mango tree), stand out. These species are traditionally used in the treatment of allergies, diarrhea, mycoses and diabetes, also acting as an antitumor, antidepressant, antimicrobial, anti-inflammatory and anxiolytic (Nivedha et al., 2020; Santos, Amaral, Silva, 2018; Santos et al., 2018; Sampaio et al., 2018). In addition to their pharmacological properties, these species are also widely studied due to their antimicrobial and antioxidant properties, which are attributed to the presence of anacardic acid, mangiferin and other compounds, such as tatrols and tannins, phenolic compounds derived from galoyl and ellagic acid compounds and chlorogenic acid (Santos et al., 2017; Cabral et al., 2016; Singh et al., 2015; Agedah, Bawo, Nyananyo, 2010).

Thus, the objective of this work was to quantify and characterize the phenolic compounds of the ethanol extracts of four species of Anacardiaceae, evaluate the antioxidant and antifungal activities against species of the genus T. rubrum, as well as the computational study of the mechanism of action against the enzyme crystal structure of aspartate semialdehyde dehydrogenase.

\section{Methodology}

\subsection{Plant material}

The collection of plant material was carried out at Cocó State Park in Fortaleza-CE, between june and december 2018. All samples were packed in plastic bags and transported to the Natural Products Chemistry Laboratory of the State University of Ceará (UECE) where the exsiccates were prepared. The botanical identification was carried out at the Herbarium Prisco Bezerra of the Federal University of Ceará - UFC, and then deposited under the exsiccate numbers shown in Table 1.

Table 1 - Identification of Anacardiaceae species collected in the Cocó State Park in Fortaleza, Ceará.

\begin{tabular}{cccc}
\hline Species & Popular name & Plant part & Register number \\
Anacardium occidentale L. & Cajueiro & Stem bark & 63659 \\
Schinopsis brasiliensis Engl. & Baraúna & Branches & 57485 \\
Spondias mombin L. & Cajazeira & Leaves & 63061 \\
Mangifera indica L. & Mangueira & Leaves & 63407 \\
\hline
\end{tabular}




\subsection{Preparation of ethanol extracts}

To prepare the extracts, 50g of dry plant material (leaves, branches and stem bark) was ground and immersed in 200 $\mathrm{mL}$ of ethanol solvent for 10 days, and then the extract was filtered and concentrated in a rotary evaporator at $60^{\circ} \mathrm{C}$ and, after this process, it was placed in a water bath $\left(40^{\circ} \mathrm{C}\right)$ until the total elimination of the solvent, obtaining the ethanol extract of the leaves (EEF), the ethanol extract of the branches (EEG) and the ethanol extract of the stem bark (EECC) (Matos, 2009).

\subsection{Quantification of total phenols}

The total phenolic contents of the extracts were determined by the Folin-Ciocateau spectrophotometric method using gallic acid as a reference standard (Sousa et al., 2007). Briefly, $100 \mu \mathrm{l}$ of each extract with $500 \mu \mathrm{l}$ of Folin Ciocalteau reagent was added to each volumetric flask for 30 seconds. Then, $6 \mathrm{~mL}$ of distilled water and $2 \mathrm{~mL}$ of $15 \%$ sodium carbonate $\mathrm{Na} 2 \mathrm{CO} 3$ were added to each flask and the mixtures were stirred again for another 1 minute, completing the volume of $10 \mathrm{~mL}$ with distilled $\mathrm{H} 2 \mathrm{O}$. The balloons were left to rest in the absence of light for 2 hours. The blank was conducted under the same conditions. After resting time, the absorbance spectra were recorded in a UV-Vis spectrophotometer at $750 \mathrm{~nm}$. The test was performed in triplicate and the same procedure was used to obtain the standard calibration curve $(y=0.127 x+0.011$, coefficient of determination $\mathrm{R} 2=0.995)$ obtained by diluting gallic acid in concentrations from 0 to $4 \mu \mathrm{g}$. mL- 1 . The results were expressed in mg of gallic acid equivalent per gram of extract (EAG.g-1), based on a standard curve prepared with gallic acid.

\subsection{Quantification of total flavonoids}

The total flavonoid content was analyzed by the colorimetric aluminum chloride method (Funari \& Ferro, 2006). Briefly, in each volumetric flask, $2 \mathrm{~mL}$ of the sample was added with $1 \mathrm{~mL}$ of $2.5 \%$ aqueous solution of aluminum chloride $\mathrm{AlCl} 3$, making up the volume of $25 \mathrm{~mL}$ with ethanol. For the blank, the same procedure was performed, substituting only the sample for ethanol. After the balloons were left to rest in the absence of light for 30 minutes, the absorbance reading was performed in a UV-Vis spectrophotometer at a wavelength of $425 \mathrm{~nm}$. All determinations were made in triplicate and the same procedure was used to obtain the standard calibration curve $(y=0.067 x+0.011$, coefficient of determination $R 2=0.999)$ obtained by diluting the isolated quercetin in concentrations from 0 to $14 \mu \mathrm{g}$. mL-1. Flavonoid content was expressed in $\mathrm{mg}$ of quercetin equivalent per gram of extract $(\mathrm{EQ} / \mathrm{g})$, based on a standard curve prepared with quercetin.

\subsection{Antioxidant activity - 2,2-diphenyl-1-picrylhydrazyl (DPPH) methodology}

The evaluation of the antioxidant capacity of the extracts of Anacardiaceae was carried out using the DPPH free radicals capture method (2.2-diphenyl-1-pricril-hydrazyl) described by Yepez et al. (2002). Each extract was weighed and diluted in order to obtain serial dilutions from the stock solution at a concentration of $10000 \mathrm{ppm}$ (15 mg of the extract solubilized in $1.5 \mathrm{~mL}$ of methanol). The ethanolic solutions obtained from the stock solution were diluted at concentrations of $5000,1000,500,100,50,10$ and $5 \mathrm{ppm}$. Once diluted, an aliquot of $0.1 \mathrm{ml}$ of each dilution was placed in test tubes, together with $3.9 \mathrm{ml}$ of the DPPH solution. Afterwards, the tubes were kept in the absence of light for 1 hour, this procedure was performed in triplicate. After the incubation period had elapsed, the absorbance of the samples was read in a UV-Vis spectrophotometer (Genesys 10S UV-Vis Thermo Scientic) at wavelengths of $515 \mathrm{~nm}$ and quercetin was used as a positive control.

The percentage of DPPH free radical inhibition by the extracts at different concentrations was calculated by expressing the scanning index in percentage (IV\%): IV\% $=($ DPPH Abs - Sample Abs / DPPH Abs) x 100. The effective concentration to inhibit 50\% of the DPPH free radical $\left(\mathrm{CE}_{50}\right)$ was obtained with the aid of the Excel 2019 software, where, 
from the values of the final concentrations of the sample and the scanning index (IV\%), scatter plots were generated whose equations of the straight lines were used for to obtain the mean and standard deviation values. For comparison purposes, a calibration curve was constructed with different percentages of the flavonoid quercetin, which has high antioxidant activity in DPPH free radicals.

\subsection{In vitro antifungal assay}

In the assay to verify the minimum inhibitory concentration (MIC) of the ethanol extracts of the studied species, strains of T. rubrum obtained from the mycothek of the Federal University of Pernambuco were used. For this assay, the broth microdilution method was used, according to the methodology described by Neves et al. (2019) with the standards of the Clinical Laboratory Standards Insitute protocol (CLSI, 2008).

The broth microdilution method was performed in 96-well microdilution plates, in which growth and sterility control in the wells were included in each strain tested. Initially, $100 \mu \mathrm{L}$ of RPMI medium was added to all wells and $10 \mathrm{mg} / \mathrm{mL}$ of extracts diluted in DMSO was added to all wells of the first column to, in sequence, make the serial dilutions. Finally, $100 \mu 1$ of the inoculum was added to the plate wells. As a control, ketoconazole was used for dermatophytes.

For susceptibility analysis, the ethanol extracts were tested at concentrations ranging from 0.002 to $2.5 \mathrm{mg} / \mathrm{mL}$. Plates were covered with parafilm and incubated at $37^{\circ} \mathrm{C}$ and visual reading was performed after five days for $T$. rubrum. All tests were performed in duplicate and MIC was defined as the lowest concentration of extract capable of inhibiting $100 \%$ of the visible growth of the fungus (Fontenelle et al., 2007). Results were determined by visualization as recommended by CLSI. The minimum fungicidal concentration (MFC) was determined by subculturing $100 \mu \mathrm{L}$ of the turbidity-free well solution in potato agar at $28^{\circ} \mathrm{C}$ (Fontenelle et al., 2007).

\subsection{Molecular docking with the enzyme aspartate semialdehyde dehydrogenase}

The structure of the enzyme aspartate semialdehyde dehydrogenase from T. rubrum was obtained from the Protein Data Bank database (https://www.rcsb.org/), deposited with the PDB 4ZIC code generated from X-Ray diffraction with resolution $2.55 \AA$, classified as oxidoreductase, organism T. rubrum BMU01672 (Li et al., 2016).

For analysis were selected phenolic compounds isolated from the studied Anacradiaceae species, which showed better atifungal activity (mangiferin, ellagic acid, isoquercitrin, quercetin, rutin and gallic acid). The bibliographic search was carried out in indexed databases of portals and periodicals (CAPES, Scielo and Google Scholar) without date restrictions. The chemical structures of the phenolic compounds for molecular docking were obtained from the PubChem repository (https://pubchem.ncbi.nlm.nih.gov/), in which the structure of mangiferin is deposited with CID5281647, ellagic acid CID5281855, isoquercitrin CID5280804, quercetin CID5280343, rutin CID5280805 and gallic acid CID370. The chemical structures were optimized using the Avogadro code (Hanwell et al., 2012), applying the MMFF94 force field (Nachbar \& Halgren, 2000).

After the preparation of the ligands and the receptor, molecular docking was performed using the AutoDock Vina program (version 1.1.2), using 3-way multithreading and Lamarkian Genetic Algorithm (Trott \& Olson, 2010). The analysis of results was performed using the programs Discovery Studio Visualizer (Biovia, 2020) and UCSF Chimera (Pettersen et al., 2004).

\subsection{Statistical analysis}

The statistical analysis was performed using the Graph Pad Prism v5.01 program, where the data were submitted to the one-way test of analysis of variance (ANOVA) to determine the statistical differences followed by the multiple comparison 
between pairs by the Tukey test, considering significant values of $\mathrm{p}<0.05$.

\section{Results and Discussion}

\subsection{Quantification of total phenols and flavonoids}

Phenolic compounds are bioactive structures, and for this reason, they are among the main antioxidants and free radical scavengers present in plants, acting to interrupt chain reactions caused by free radicals due to their ability to donate hydrogen atoms (Torres et al., 2018; Penido et al., 2017). The quantitative estimate of total phenols and flavonoids show statistical differences between most of the ethanol extracts of the different studied plant species (Table 2). Among the species of Anacardiaceae surveyed, the total phenol content ranged from 227.47 to $493.44 \mathrm{EAG} / \mathrm{g}$, while the flavonoid levels showed high variability among the species tested, from 12.28 to $86.07 \mathrm{EQ} / \mathrm{g}$. High levels of total phenols and flavonoids were detected all species in this study.

Table 2 - Content of total phenols and flavonoids and antioxidant activity $\left(\mathrm{EC}_{50}\right)$ against the $\mathrm{DPPH}^{*}$ radical of Anacardiaceae species.

\begin{tabular}{lccc}
\hline Species & $\begin{array}{c}\mathbf{1}^{\text {Phenols GAE/g }} \\
\text { extract }\end{array}$ & $\begin{array}{c}{ }^{\mathbf{2}} \text { Flavonoids EQ/g } \\
\text { extract }\end{array}$ & ${ }^{\mathbf{3}} \mathbf{D P P H} \boldsymbol{\mu \mathbf { g } / \mathbf { m L }}$ \\
\hline A. occidentale & $452.53^{\mathrm{a}} \pm 15.15$ & $14.86^{\mathrm{c}} \pm 0.22$ & $4.04^{\mathrm{a}} \pm 0.12$ \\
S. brasiliensis & $227.47^{\mathrm{c}} \pm 18.62$ & $12.28^{\mathrm{d}} \pm 0.60$ & $11.21^{\mathrm{c}} \pm 0.49$ \\
S. mombin & $297.46^{\mathrm{b}} \pm 26.94$ & $19.99^{\mathrm{b}} \pm 0.44$ & $3.73^{\mathrm{a}} \pm 0.12$ \\
M. indica & $493.44^{\mathrm{a}} \pm 13.89$ & $86.07^{\mathrm{a}} \pm 1.67$ & $7.29^{\mathrm{b}} \pm 0.38$ \\
Quercetin & - & - & $1.32 \pm 0.05$ \\
\hline
\end{tabular}

All analyses were performed in triplicate and the results were expressed as mean \pm standard deviation. Different letters denote statistical difference between the values of each column ( $\mathrm{p}<0.05$ ). ${ }^{1}$ Milligram Equivalent to Gallic Acid per gram of extract; ${ }^{2}$ Miligram Equivalent to Quercetin per gram of extract; ${ }^{3}$ Effective concentration to inhibit 50\% of the free radical DPPH (2,2-diphenyl-1-picryl-hydrazil). Source: Authors.

Comparison with literature data is difficult, since few studies have been carried out previously with the same species and, even when the species were the same, they originated from other regions. Another problem is the use of different reference standards and different extraction solvents. Literature data on the content of phenolic compounds of methanolic extract obtained by different methods of extraction from the bark of stem, leaves and cashew nuts of A. occidentale, presented a phenol range from $593.47 \pm 0.05$ to $660.07 \pm 3.95 \mathrm{mg}$ EAG/100g and flavonoids from $70.39 \pm 0.06$ to $81.17 \pm 1.08 \mathrm{mg}$ $\mathrm{EQ} / 100 \mathrm{~g}$ (Salomon et al., 2018).

The hydroalcoholic extract prepared from S. brasiliensis stem bark by Fernandes et al. (2015), showed a polyphenol and flavonoid content of $24.52 \mu \mathrm{g} \mathrm{EAG} / \mathrm{mg}$ and $1.43 \mu \mathrm{g} \mathrm{EQ} / \mathrm{mg}$, respectively, showing a lower potential than the samples found in this study. Furthermore, the content of phenols found in the methanol extract of S. mombin leaves by Omoregie \& Oikeh, (2015) was $213.50 \pm 1.25 \mathrm{mg}$ EAG/g and $78.75 \pm 0.42 \mathrm{mg}$ EQ of flavonoids $/ \mathrm{g}$, where the profile of total phenols was lower than the sample of this study and the content of flavonoids was higher. Ethanol extract prepared from seeds of M. indica fruits had a phenolic content of $8.57 \pm 0.3 \mathrm{mg}$ EAG/100mg (Abdullah et al., 2015). It is known that the qualitative and quantitative variations of phenolic compounds presented by the species of Anacardiaceae studied may be conditioned by environmental, genetic and morphological factors which directly influence the production of these metabolites, causing a 
variation in the chemical composition of plants of the same species and region (Mohamed et al., 2016; Gobbo-Neto \& Lopes, 2007).

\subsection{Antioxidant activity}

The antioxidant potential of the ethanol extracts of four species of Anacaradiaceae was quantified as the concentration needed to inhibit $50 \%$ of the DPPH radical $\left(\mathrm{EC}_{50}\right.$ ) (Table 2). This method has been widely used to determine the antioxidant activities of food and vegetable components due to its speed, sensitivity and simple execution (Andrade et al., 2018). The results show that $\mathrm{EC}_{50}$ values ranged from $3.73 \pm 0.12$ to $11.21 \pm 0.49 \mu \mathrm{g} / \mathrm{mL}$. S. mombin extract was the best DPPH inhibitor, followed by A. occidentale, M. indica and S. brasiliensis. The EECC A. occidentale and the S. mombin EEF did not show statistical differences. The variation observed in $\mathrm{EC}_{50}$ values among the species studied may be associated with differences in the contents of phenolic compounds and other constituents present in the samples (Rahimmalek et al., 2020).

Similar to our results, previous studies revealed the antioxidant potential of Anacardiaceae species, attributing this activity to the presence of phenolic compounds (Santos et al., 2017; Cabral et al., 2016; Abdullah et al., 2015; Ajileye et al., 2015). The antioxidant activity performed by plant extracts may be due to their secondary metabolites, including flavonoids and other phenolic compounds. The scavenging of free radicals by these metabolites is especially attributed to their oxidationreduction capacity, acting directly in the absorption and neutralization of free radicals. This antioxidant protection will directly interfere with the formation of lesions and loss of cell integrity (Mendes et al., 2021).

\subsection{Antifungal activity}

Table 3 shows the results of the antifungal activity of plant extracts on T. rubrum strains. Holetz et al. (2002) classified the antimicrobial efficacy of plant extracts as good (MIC $<100 \mu \mathrm{g} / \mathrm{mL}$ ), moderate (MIC, $100-500 \mu \mathrm{g} / \mathrm{mL}$ ), weak (MIC, $500-1000 \mu \mathrm{g} / \mathrm{mL}$ ) and inactive (MIC $>1000 \mu \mathrm{g} / \mathrm{mL}$ ). It is observed that the extract with the most expressive antifungal activity against all the tested fungi was the EECC of A. occidentale at a concentration of $39 \mu \mathrm{g} / \mathrm{mL}$. It should be noted that the S. mombin EEF presented MIC ranging from 39 to $78 \mu \mathrm{g} / \mathrm{mL}$ against dermatophytes, demonstrating good inhibitory activity. For the EEF of M. indica it was found good activity against the species of T. rubrum (5908 and 6213) with MIC ranging from 78 to $39 \mu \mathrm{g} / \mathrm{mL}$, respectively. However, T. rubrum strains (6753 and 6205) were not inhibited by the M. indica extract. Similar activity was observed for $S$. brasiliensis EEG, which showed moderate antifungal activity with a MIC of $150 \mu \mathrm{g} / \mathrm{mL}$ against $T$. rubrum (6753, 6205 and 5908) and good activity against $T$. rubrum 6213 with a MIC of $39 \mu \mathrm{g} / \mathrm{mL}$.

Table 3 - Minimum Inhibitory Concentration (MIC) and Minimum Fungicidal Concentration (MFC) of ethanolic extracts of Anacardiaceae species against T. rubrum

\begin{tabular}{|c|c|c|c|c|}
\hline Strains & T. rubrum (6753) & T. rubrum (6205) & T. rubrum (5908) & T. rubrum (6213) \\
\hline & $\begin{array}{c}\text { MIC MFC } \\
\mu \mathrm{g} / \mathrm{mL}\end{array}$ & $\begin{array}{c}\text { MIC MFC } \\
\mu \mathrm{g} / \mathrm{mL}\end{array}$ & $\begin{array}{c}\text { MIC MFC } \\
\mu \mathrm{g} / \mathrm{mL}\end{array}$ & $\begin{array}{c}\text { MIC MFC } \\
\mu \mathrm{g} / \mathrm{mL}\end{array}$ \\
\hline A. occidentale & 3978 & 3978 & 3978 & 3978 \\
\hline S. brasiliensis & $150 \quad 310$ & $150 \quad 310$ & $150 \quad 310$ & 3978 \\
\hline S. mombin & $78 \quad 150$ & $78 \quad 150$ & 3978 & $78 \quad 150$ \\
\hline M. indica & 25005000 & $2500 \quad 5000$ & $78 \quad 150$ & 3978 \\
\hline ketoconazole & 0.25 & 0.25 & 0.25 & 0.25 \\
\hline
\end{tabular}

Source: Authors. 
This study confirmed that the studied Anacardiaceae species have antifungal properties against dermatophytes. Thus, the results confirm the ethnopharmacological use of these plants as antimicrobial agents. In line with our results, previous studies using different parts of the species studied here, as well as isolated compounds, extracts, antifungal methods and other fungal species, also revealed inhibition potential (Disegha \& Akani, 2017; Temitope et al., 2017; Kannan et al., 2009).

All extracts showed considerable amounts of phenolic compounds, which may be involved in the antifungal activity observed in this study. Research has shown that the antifungal potential of plant extracts is strongly influenced by the quantitative and qualitative variations of their phenolic compounds, including flavonoids. As for the antifungal action mechanism demonstrated by these phenolic substances, there are the disruption of the cell membrane, inhibition of cell division, the development of hyphae through targets in specific genes, as well as interference in metabolic pathways and/or inducing apoptosis by disturbing redox homeostasis (Lagrouh, Dakka, Bakri \& 2017; Mohamed et al., 2016).

\subsection{Molecular docking}

Studies using ethanol extracts prepared from flowers, leaves and stem bark of A. occidentale identified the presence of gallic acid in all samples (Silva et al., 2016). Quercetin, on the other hand, was reported from extracts from the leaves of this species. This flavonoid was effective against different strains of $T$. rubrum, reducing the ergosterol content in these microorganisms (Bitencourt et al., 2013; Ayra et al., 1989). Rutin has also been identified in A. occidentale leaves (Chotphruethipong, Benjakul, Kijroongrojana, 2017). This compound has been shown to be effective against different bacteria and also in the treatment of arthritis caused by Candida albicans (Oliveira et al., 2016).

Tests carried out with the pulp of $M$. indica showed the presence of some phenolic compounds, including gallic acid (Palafox-Carlos, Yahia \& González-Aguilar, 2012). Mangiferin was also identified in this species, which showed antifungal activity against filamentous fungi (Singh et al., 2012). Gallic acid is reported to inhibit the growth of many fungal species such as $C$. albicans and T. rubrum in vitro and in vivo assays. For T. rubrum species, gallic acid also decreases the ergosterol content, inhibiting the enzymes sterol 14 $\alpha$-desmethylase and squalenopoxidase (Li et al., 2017).

For S. mombin, studies with the hydroethanolic extract of the leaves of this species allowed the identification and quantification of ellagic acid (Cabral et al., 2016) and isoquercitrin (Santos et al., 2018). Studies have shown that ellagic acid has a broad spectrum of antifungal activity in vitro, being the best activity observed against $T$. rubrum. As for in vivo trials, topical administration of ellagic acid was shown to significantly increase the cure rate in a guinea pig infection model of $T$. rubrum ( $\mathrm{Li}, \mathrm{Guo} \&$ Aibai, 2015). Isoquercitrin is a flavonoid that acts as a potent antifungal agent, targeting the cell membrane, causing permeabilization and depolarization of this structure (Yun et al., 2015). Fernandes et al. 2015 also observed gallic acid in the hydroalcoholic extract of S. brasiliensis stem bark.

In this study, some phenolic compounds presented in A. occidentale, M. indica, S. mombin and S. brasiliensis, as above described, were chosen to evaluate their molecular docking with the enzyme aspartate semialdehyde dehydrogenase from T. rubrum. Among them, the phenolic compounds mangiferin, ellagic acid, isoquercitrin, rutin, quercetin and gallic acid, which stand out for their antifungal activity (Figure 1). The computational study will enable to compare the antifungal potential of these phenolic compounds against T. rubrum. 
Figure 1 - Antifungal phenolic compounds present in Anacardiaceae species.<smiles>O=C(O)c1cc(O)c(O)c(O)c1</smiles>

Gallic Acid

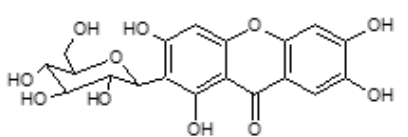

Mangiferin

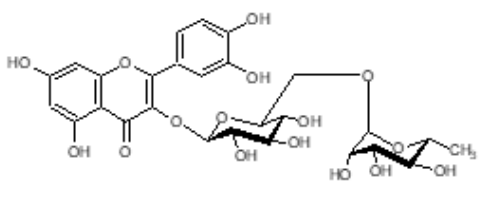

Rutin<smiles></smiles>

Ellagic acid<smiles>O=c1c(OC2O[C@H](CO)[C@@H](O)[C@H](O)[C@H]2O)c(-c2ccc(O)c(O)c2)oc2cc(O)cc(O)c12</smiles>

Isoquercitrin<smiles></smiles>

Quercetin

Source: Authors.

In the molecular docking with the enzyme aspartate semialdehyde dehydrogenase from T. rubrum, after simulations, it was possible to observe that all ligands presented ideal RMSD values (Table 4), less than $2 \AA$ (Yusuf et al., 2008). Regarding the binding energy of the formed complexes, it was possible to observe that all phenolic compounds under study showed high affinity for the enzyme, being more favorable to mangiferin $(-9.9 \mathrm{kcal} / \mathrm{mol})$, ellagic acid $(-9.6 \mathrm{kcal} / \mathrm{mol})$, isoquercitrin $(-9.4$ $\mathrm{kcal} / \mathrm{mol})$, quercetin $(-9.1 \mathrm{kcal} / \mathrm{mol})$, rutin $(-8.5 \mathrm{kcal} / \mathrm{mol})$ and gallic acid $(-7.6 \mathrm{kcal} / \mathrm{mol})$. Five ligands were more favorable to interact with the protein target than fluconazole, and gallic acid was similar to this reference antifungal (Figure 2).

Table 4 - Affinity energy and RMSD values of complexes formed after docking simulations against T. rubrum.

\begin{tabular}{lcc}
\hline \multirow{2}{*}{ Ligands } & \multicolumn{2}{c}{ T. rubrum } \\
\cline { 2 - 3 } & Energy & RMSD \\
& $(\mathrm{kcal} / \mathrm{mol})$ & 1.798 \\
\hline Mangiferin & -9.9 & 0.053 \\
Ellagic acid & -9.6 & 1.582 \\
Isoquercitrin & -9.4 & 1.63 \\
Quercetin & -9.1 & 1.65 \\
Rutin & -8.5 & 0.022 \\
Gallic acid & -7.6 & 1.504 \\
Fluconazole & -7.6 & \\
\hline
\end{tabular}


The formed complexes showed interactions varying between $1.92 \AA$ and $5.73 \AA$ in distance (Table 5), and it is possible to identify as the most relevant bonds of the mangiferin complex, five strong-intensity hydrogen bonds (Imberty et al., 1991) with the ASN9A residues, GLU278A, ARG297A, ARG312A, SER618B and two medium intensities with ARG312A and LYS598B. In the case of ellagic acid, the most prominent bonds were three hydrophobic interactions with ALA162A, GLN282A, LYS598B and two strong hydrogen bonds with GLN282A and ARG312A. With the compound isoquercitrin it was possible to observe two hydrophobic interactions with LYS598B, GLN623B and five strong hydrogen bonds with residues SER277A, GLU278A, GLN282A, TYR284A and LEU621B.

Table 5 - Types of interactions and distances $(\AA)$ between the ligands and the amino acid residues aspartate semialdehyde dehydrogenase from T. rubrum.

\begin{tabular}{|c|c|c|c|c|}
\hline Receptor & Ligand & Residues & Interaction & Distance $(\AA)$ \\
\hline \multirow{43}{*}{$\begin{array}{l}\text { Aspartate semialdehyde } \\
\text { dehydrogenase with NADP } \\
\text { from } T \text {. rubrum }\end{array}$} & \multirow{9}{*}{ Mangiferin } & ASN819A & H-Bond (weak) & 3.64 \\
\hline & & LYS821A & H-Bond (strong) & 3.03 \\
\hline & & ARG824A & H-Bond ( average ) & 3.25 \\
\hline & & ASN863A & H-Bond (strong) & 3.01 \\
\hline & & CYS864A & H-Bond (strong) & 2.39 \\
\hline & & GLY896A & H-Bond (strong) & 1.92 \\
\hline & & GLY898A & H-Bond ( average ) & 3.28 \\
\hline & & GLU918A & H-Bond (strong) & 2.50 \\
\hline & & LYS921A & H-Bond (strong) & 2.27 \\
\hline & \multirow[t]{9}{*}{ Ellagic acid } & ALA701C & Hydrophobic & 3.35 \\
\hline & & ALA374C & H-Bond (strong) & 2.79 \\
\hline & & VAL375C & H-Bond (strong) & 2.61 \\
\hline & & ASP444C & H-Bond (average) & 3.47 \\
\hline & & ASN465C & H-Bond (strong) & 2.17 \\
\hline & & ARG470C & H-Bond (strong) & 2.65 \\
\hline & & CYS510C & H-Bond (strong) & 2.62 \\
\hline & & GLY544C & H-Bond (strong) & 2.21 \\
\hline & & GLY700C & H-Bond (strong) & 2.35 \\
\hline & \multirow[t]{8}{*}{ Isoquercitrin } & TYR545C & Hydrophobic & 3.79 \\
\hline & & ARG470C & H-Bond (strong) & 2.30 \\
\hline & & ARG470C & H-Bond (strong) & 2.58 \\
\hline & & SER508C & H-Bond (strong) & 2.37 \\
\hline & & CYS510C & H-Bond (strong) & 3.32 \\
\hline & & GLY544C & H-Bond (strong) & 2.82 \\
\hline & & TYR545C & H-Bond (strong) & 3.04 \\
\hline & & LYS567C & H-Bond (strong) & 2.49 \\
\hline & \multirow[t]{11}{*}{ Quercetin } & VAL731A & Hydrophobic & 3.70 \\
\hline & & ASN819A & H-Bond (strong) & 3.09 \\
\hline & & ARG824A & H-Bond (strong) & 2.53 \\
\hline & & ARG824A & H-Bond (strong) & 2.28 \\
\hline & & ARG824A & H-Bond (average) & 2.47 \\
\hline & & CYS864A & H-Bond (strong) & 3.50 \\
\hline & & GLY898A & H-Bond (strong) & 1.94 \\
\hline & & TYR899A & H-Bond (strong) & 2.39 \\
\hline & & TYR899A & H-Bond (strong) & 2.86 \\
\hline & & LYS921A & H-Bond (strong) & 2.64 \\
\hline & & ASN1050A & H-Bond (strong) & 3.45 \\
\hline & \multirow[t]{6}{*}{ Rutin } & ARG409C & Hydrophobic & 3.84 \\
\hline & & ARG409C & H-Bond (strong) & 2.59 \\
\hline & & ARG409C & H-Bond (strong) & 2.43 \\
\hline & & GLY898A & H-Bond (strong) & 2.87 \\
\hline & & GLY898A & H-Bond (strong) & 2.49 \\
\hline & & GLY901A & H-Bond (strong) & 2.44 \\
\hline
\end{tabular}




\begin{tabular}{lccc}
\hline & VAL902A & H-Bond (strong) & 2.57 \\
& VAL902A & H-Bond (strong) & 2.77 \\
& ARG954A & H-Bond (strong) & 2.56 \\
& ARG409C & $\pi$-Cation & 5.73 \\
& PRO602C & Hydrophobic & 3.61 \\
& PHE908A & Hydrophobic & 3.97 \\
& ASP199D & H-Bond (average) & 3.24 \\
& PRO246D & H-Bond (strong) & 2.24 \\
& ASP555C & H-Bond (strong) & 2.19 \\
& PRO602C & H-Bond (strong) & 2.25 \\
& ASP909A & H-Bond (strong) & 2.55 \\
& PHE554C & $\pi-$-Stacking & 4.81 \\
& PRO799A & Hydrophobic & 3.66 \\
& TYR899A & Hydrophobic & 3.47 \\
& ASN819A & H-Bond (average) & 2.74 \\
& LYS921A & $\pi$-Cation & 3.54 \\
\hline
\end{tabular}

Hidrogen bond classification: $2,5 \AA<\mathrm{d}<3,1 \AA=$ Strong interaction; $3,1 \AA<\mathrm{d}<3,55 \AA$ = Average interaction; $\mathrm{d}>3,55 \AA=$ Weak interaction. Source: Imberty et al. (1991).

The quercetin complex had five hydrogen bonds, four of which were of strong intensity with ALA11A, GLU278A, ARG297A, ARG312A and one of medium intensity with SER277A. Quercetin also showed a $\pi$-Stacking interaction with PHE281A and a $\pi$-Cation with ARG312A. Regarding the rutin complex, three hydrophobic interactions with PRO670B, ASP263A, LYS271A, four strong hydrogen bonds with SER273A, SER614B, one of medium intensity with SER654B and two weak with the residue LYS271A were highlighted. The gallic acid complex showed two hydrophobic interactions with ILE372B, ARG462B, six hydrogen bonds, four of which were of strong intensity with ILE354B, THR355B, ARG462B, GLY561B and two of medium intensity with the residues ASP428B and SER430B. Regarding the fluconazole reference antifungal complex, it was possible to observe two hydrophobic interactions with PRO799A, TYR899A, a hydrogen bond with the residue ASN819A and a $\pi$-Cation interaction with LYS921A.

Considering the importance of the number of hydrogen bonds for the stability of the complexes (Du et al., 2016; Milenković et al., 2020), it is possible to infer the order of stability of the complexes, with quercetin standing out as the most stable (ten H-Bond), followed by mangiferin (nine H-Bond), ellagic acid and rutin (eight H-Bond), isoquercitrin (seven $\mathrm{H}$ Bond) and gallic acid (five H-Bond) (Table 5). The complexes of all ligands were more stable against the complex of the drug Fluconazole (an H-Bond), a reference antifungal. 
Figure 2 - Interaction complex of the enzyme aspartate semialdehyde dehydrogenase from T. rubrum with ligands (A). 2D map of interactions of the ligand gallic acid (B), rutin (C), mangiferin (D), quercetin (E), isoquercitrin (F) and ellagic acid (G) with the protein target.

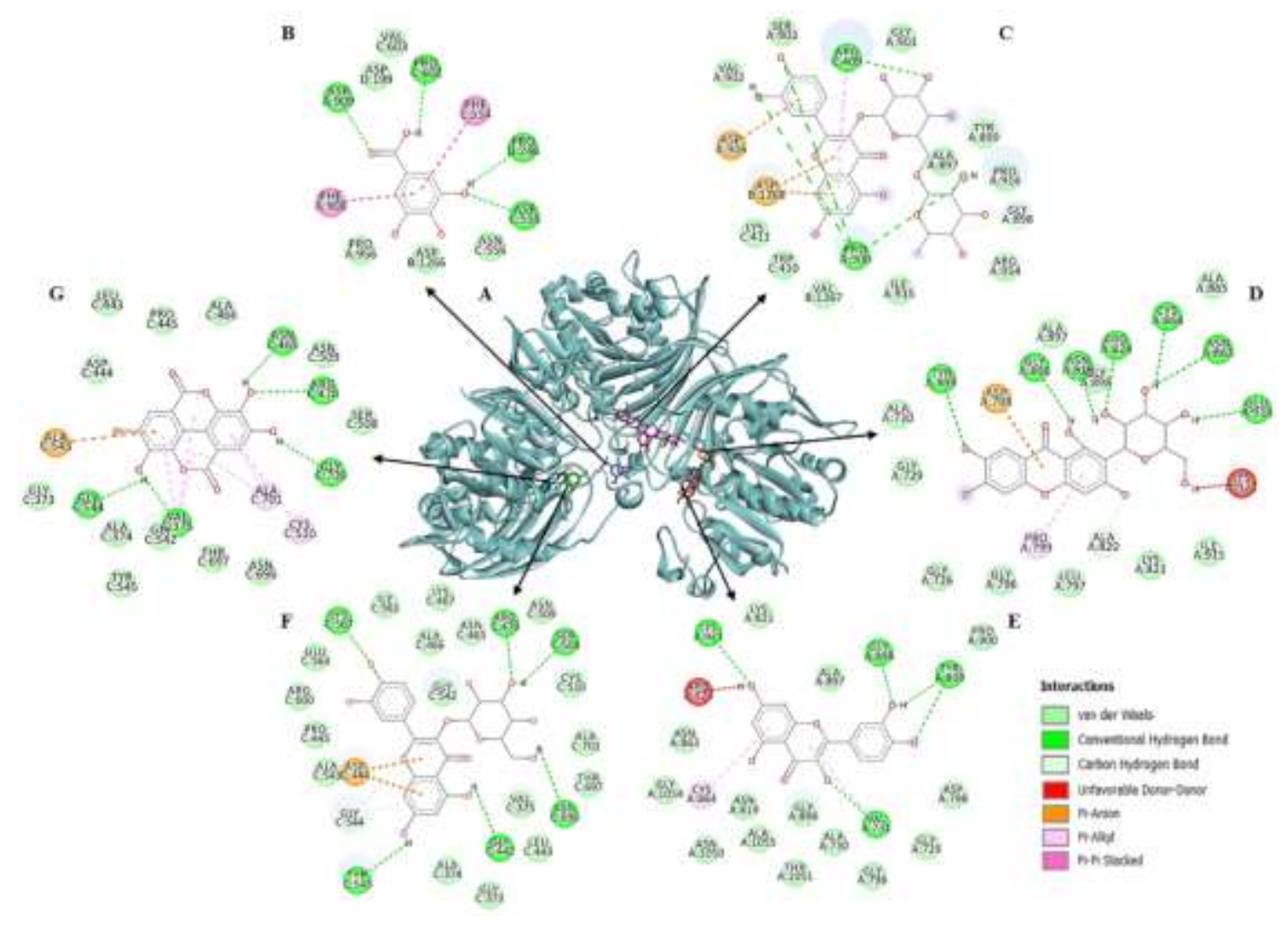

Source: Authors.

\section{Conclusion}

The findings research show that the species studied presented relevant levels of phenolic compounds, as well as an antioxidant and antifungal effect. As for molecular docking, the compounds rutin, isoquercitrin, quercetin, ellagic acid and mangiferin, showed high affinity for the enzyme aspartate semialdehyde dehydrogenase from T. rubrum, thus demonstrating that several phenolic compounds from Anacardiaceae species are important natural products that inhibit fungal development. Thus, the selected medicinal species are promising sources of natural products that can be used in further studies to discover new therapeutic compounds against fungal infections. However, future research will be needed to elucidate the antioxidant and antifungal mechanisms in vivo, as well as the bioavailability and metabolic pathways involved.

\section{Acknowledgments}

This research received funding from Fundação Cearense de Apoio ao Desenvolvimento Científico e Tecnológico (Funcap) and Conselho Nacional de Desenvolvimento Científico e Tecnológico (CNPq).

\section{References}

Abdullah, A. H., Mohammed, A. S., \& Abdullah, R. (2015). Identification and quantification of phenolic compounds in Mangifera indica waterlily kernel and their free radical scavenging activity. Journal of Advanced Agricultural Technologies, 2(1), 1-7. https://doi.org/10.12720/joaat.2.1.1-7. 
Agedah, C. E., Bawo, D. D. S., \& Nyananyo, B. L. (2010). Identification of antimicrobial properties of cashew, Anacardium occidentale L. (Family Anacardiaceae). Journal of Applied Science and Environmental Management, 14(3), 25-27. https://doi.org/ 10.4314/jasem.v14i3.61455.

Arya, R., Babu, V., \& Ilyas, M. (1989). Phytochemical examination of the leaves of Anacardium-occidentale. Journal of the Indian Chemical Society, 66(1), 67-68.

Ajileye, O. O., Obuotor, E. M., Akinkunmi, E. O., \& Aderogba, M. A. (2015). Isolation and characterization of antioxidant and antimicrobial compounds from Anacardium occidentale L. (Anacardiaceae) leaf extract. Journal of King Saud University-Science, 27(3), 244-252. https://doi.org/10.1016/j.jksus.2014.12.004.

Akroum, S. (2018). Antifungal activity of camellia sinensis crude extracts against four species of Candida and Microsporum persicolor. Journal de mycologie medicale, 28(3), 424-427. https://doi.org/10.1016/j.mycmed.2018.06.003.

Andrade, L. B. D. S., Julião, M. S. D. S., Cruz, R. C. V., Rodrigues, T. H. S., Fontenelle, R. O. D. S., \& Silva, A. L. C. D. (2018). Antioxidant and antifungal activity of carnauba wax powder extracts. Industrial Crops and Products, 125(1), 220-227. https://doi.org/10.1016/j.indcrop.2018.09.004.

Araújo, A. A. D., Soares, L. A. L., Ferreira, M. R. A., Neto, M. A. D. S., Silva, G. R. D., Araújo Júnior, R. F. D., Guerra, G. C. B., \& Melo, M. C. N. D. (2014). Quantification of polyphenols and evaluation of antimicrobial, analgesic and anti-inflammatory activities of aqueous and acetone-water extracts of Libidibia ferrea, Parapiptadenia rigida and Psidium guajava. Journal of ethnopharmacology, 156(28), 88-96. https://doi.org/10.1016/j.jep.2014.07.031.

Bardakci, H., Celep, E., Gözet, T., Kan, Y., \& Kirmizibekmez, H. (2019). Phytochemical characterization and antioxidant activities of the fruit extracts of several Crataegus taxa. South African Journal of Botany, 124, 5-13. https://doi.org/10.1016/j.sajb.2019.04.012.

BIOVIA SDDS (2020) Discovery studio visualizer.

Bitencourt, T. A., Komoto, T. T., Massaroto, B. G., Miranda, C. E. S., Beleboni, R. O., Marins, M., \& Fachin, A. L. (2013). Trans-chalcone and quercetin down-regulate fatty acid synthase gene expression and reduce ergosterol content in the human pathogenic dermatophyte Trichophyton rubrum. BMC complementary and alternative medicine, 13(1), 1-6. http://www.biomedcentral.com/1472-6882/13/229.

Cabral, B., Siqueira, E., Bitencourt., M. A., Lima, M. C., Lima, A. K., Ortmann, C. F., \& Reginatto, F. H. (2016). Phytochemical study and anti-inflammatory and antioxidant potential of Spondias mombin leaves. Revista Brasileira de Farmacognosia, 26(3), 304-311. http://dx.doi.org/10.1016/j.bjp.2016.02.002.

Clinical And Laboratory Standards Institute (CLSI). (2018). Reference Method for Broth Dilution Antifungal Susceptibility Testing of Filamentous Fungi (Approved Standard Document M38. CLSI). Clinical and Laboratory Standards Institute (CLSI). (2a ed.). Wayne, PA.

Chotphruethipong, L., Benjakul, S., \& Kijroongrojana, K. (2017). Optimization of extraction of antioxidative phenolic compounds from cashew (Anacardium occidentale L.) leaves using response surface methodology. Journal of Food Biochemistry, 41(4), 1-10. https://doi.org/10.1111/jfbc.12379.

Disegha, G. C., \& Akani, N. P. (2017). Antifungal activity of Mangifera indica leaf extracts on selected fungi. Science and Technology, 4(2), 136-148. https://www.researchgate.net/profile/Nedie-Akani/publication/331574530.

Du, X., Li, Y., Xia, Y. L., Ai, S. M., Liang, J., Sang, P., Ji, X. L., \& Liu, S. Q. (2016). Insights into protein-ligand interactions: mechanisms, models, and methods. International journal of molecular sciences, 17(2), 144. https://doi.org/10.3390/ijms17020144.

Espino, M., Solari, M., Fernández, D. L. A. M., Boiteux, J., Gómez, M. R., \& Silva, M. F. (2019). NADES-mediated folk plant extracts as novel antifungal agents against Candida albicans. Journal of pharmaceutical and biomedical analysis, 167(15), 15-20. https://doi.org/10.1016/j.jpba.2019.01.026.

Fernandes, F. H., Batista, R. S. D. A., Medeiros, F. D. D., Santos, F. S., \& Medeiros, A. C. (2015). Development of a rapid and simple HPLC-UV method for determination of gallic acid in Schinopsis brasiliensis. Revista Brasileira de Farmacognosia, 25(3), 208-211. https://doi.org/10.1016/j.bjp.2015.05.006 .

Fontenelle, R. O. S., Morais, S. M., Brito, E. H. S., Kerntopf, M. R., Brilhante, R. S. N., Cordeiro, R. A., Tome, A. R., Queiroz, M. G. R., Nascimento, N. R. F., Sidrim, J. J. C., \& Rocha, M. F. G. (2007). Chemical composition, toxicological aspects and antifungal activity of essential oil from Lippia sidoides Cham. Journal of Antimicrobial Chemotherapy, 59(5), 934-940. https://doi.org/10.1093/jac/dkm066.

Funari, C. S., \& Ferro, V. O. (2006). Análise de própolis. Ciência e Tecnol. Aliment, 26(1), 171-178. https://doi.org/10.1590/S0101-20612006000100028.

Gobbo-Neto, L., \& Lopes, N. P. (2007). Plantas medicinais: fatores de influência no conteúdo de metabólitos secundários. Quim. Nova, 30(2), 374-381. https://doi.org/10.1590/S0100-40422007000200026

Hanwell, M. D., Curtis, D. E., Lonie, D. C., Vandermeersch, T., Zurek, E., \& Hutchison, G. R. (2012). Avogadro: an advanced semantic chemical editor, visualization, and analysis platform. Journal of cheminformatics, 4(1), 1-17. http://www.jcheminf.com/content/4/1/17.

Holetz, F. B., Pessini, G. L., Sanches, N. R., Cortez, D. A. G., Nakamura, C. V., \& Dias Filho, B. P. (2002). Screening of some plants used in the Brazilian folk medicine for the treatment of infectious diseases. Memórias do Instituto Oswaldo Cruz, 97(7), 1027-1031. https://doi.org/10.1590/S007402762002000700017.

Imberty, A., Hardman, K. D., Carver, J. P., \& Perez, S. (1991). Molecular modelling of protein-carbohydrate interactions. Docking of monosaccharides in the binding site of concanavalin A. Glycobiology, 1(6), 631-642. https://doi.org/10.1093/glycob/1.6.631.

Kannan, R. V., Sumathi, C.S., Balasubramanian, V., \& Ramesh, N. (2009). Elementary chemical profiling and antifungal properties of cashew (Anacardium occidentale L.) nuts. Botany Research International, 2(4), 253-257. https://www.researchgate.net/profile/Ramesh-Nachimuthu/publication/237358357.

Lagrouh, F., Dakka, N., \& Bakri, Y. (2017). The antifungal activity of Moroccan plants and the mechanism of action of secondary metabolites from plants. Journal de mycologie medicale, 27 (3), 303-311. https://doi.org/10.1016/j.mycmed.2017.04.008. 
Li, Z. J., Liu, M., Dawuti, G., Dou, Q., Ma, Y., Liu, H. G., \& Aibai, S. (2017). Antifungal activity of gallic acid in vitro and in vivo. Phytotherapy research, 31(7), 1039-1045. https://doi.org/10.1002/ptr.5823.

Li, Q., Mu, Z., Zhao, R., Dahal, G., Viola, R.E., Liu, T., Jin, Q., \& Cui, S. (2016) Structural Insights into the Tetrameric State of Aspartate- $\beta$-semialdehyde Dehydrogenases from Fungal Species. Scientific reports, 6(1), 1-13. https://doi.org/10.1038/srep21067.

Li, Z. J., Guo, X., Dawuti, G., \& Aibai, S. (2015). Antifungal activity of ellagic acid in vitro and in vivo. Phytotherapy Research, 29(7), 1019-1025. https://doi.org/10.1002/ptr.5340.

Luna, M. S. M., De Paula, R. A., Costa, R. B., Dos Anjos, J. V., Da Silva, M. V.; \& Correia, M. T. S. (2020). Bioprospection of Libidibia ferrea var. ferrea: Phytochemical properties and antibacterial activity. South African Journal of Botany, 130, 103-108. https://doi.org/10.1016/j.sajb.2019.12.013.

Madikizela, B., Aderogba, M. A., \& Van Staden, J. (2013). Isolation and characterization of antimicrobial constituents of Searsia chirindensis L. (Anacardiaceae) leaf extracts. Journal of ethnopharmacology, 150 (2), 609-613. https://doi.org/10.1016/j.jep.2013.09.016.

Matos, F.J.A. Introdução à Fitoquímica Experimental. (2009). (3a ed.), UFC. 150p.

Mendes, F. E. T., Miranda, G. M., Camilo, H. K. V. S.; Lira, R. D. S., Bitu, V. D. C. L., \& Souza, C. E. S. (2021). Avaliação da atividade antimicrobiana, antioxidante e citoprotetora da quercetina contra a ação tóxica do cloreto de bário. Research, Society and Development, 10(6), 1-8. http://dx.doi.org/10.33448/rsd-v10i6.15632.

Mohamed, M. S., Saleh, A. M., Abdel-Farid, I. B., \& El-Naggar, S. A. (2016). Growth, hydrolases and ultrastructure of Fusarium oxysporum as affected by phenolic rich extracts from several xerophytic plants. Pesticide biochemistry and physiology, 141, 57-64. https://doi.org/10.1016/j.pestbp.2016.11.007.

Morais, S. M., Silva Lopes, F. F., Fontenele, G. A., Silva, M. V. F., Fernandes, V. B., \& Alves, D. R. (2021). Total phenolic content and antioxidant and anticholinesterase activities of medicinal plants from the State's Cocó Park (Fortaleza-CE, Brazil). Research, Society and Development, 10(5), 1-12. http://dx.doi.org/10.33448/rsd-v10i5.14493.

Milenković, D. A., Dimić, D. S., Avdović, E. H., \& Marković, Z. S. (2020). Several coumarin derivatives and their Pd (II) complexes as potential inhibitors of the main protease of SARS-CoV-2, an in silico approach. RSC Advances, 10(58), 35099-35108. https://doi.org 10.1039/D0RA07062A

Nachbar RB, Halgren TA (2000) Merck Molecular Force Field. IV. Conformational Energies and Geometries for MMFF94. Journal Computational Chemistry, 17(5-6), 587-651. https://doi.org/10.1002/(SICI)1096-987X.

Nascimento, P. P. S., Ferraz- Carvalho, R. S., Silva, T. S., Araújo, T. A. S., Amorim, E. L. C., Pereira, M. A., \& Cavalcanti, I. M. F. (2021). Interaction between bark extract of Anadenanthera colubrina var. cebil (Griseb.) Altschul with antibiotics against methicillin-resistant Staphylococcus aureus (MRSA). Research, Society and Development, 10(6), 1-10. http://dx.doi.org/10.33448/rsd-v10i6.15469.

Neves, A. M., Santos Silva, H., Sousa, E. B., Santos Fontenelle, R. O., Silva, A. C., \& Morais, S. M. (2019). Perfil fitoquímico e avaliação da atividade antifúngica da fração hexânica de Mitracarpus baturitensis (Rubiaceae). Essentia-Revista de Cultura, Ciência e Tecnologia da UVA, 20(1), 96-101. https://doi.org/10.36977/ercct.v20i1.241.

Nivheda, k., Sivasakthi, S., Prakash, A., Devipriya, N., \& Vadivel, V. (2020). In vitro studies on antioxidant and cyto-protective activities of polyphenol-rich fraction isolated from Mangifera indica leaf. South African Journal of Botany, 130, 396-406. https://doi.org/10.1016/j.sajb.2020.01.019.

Oliveira, V. M., Carraro, E., Auler, M. E., \& Khalil, N. M. (2016). Quercetin and rutin as potential agents antifungal against Cryptococcus spp. Brazilian Journal of Biology, 76(4), 1029-1034. https://doi.org/10.1590/1519-6984.07415.

Omoregie, E. S., \& Oikeh, E. I. (2015). Comparative studies on the phytochemical composition, phenolic content and antioxidant activities of methanol leaf extracts of Spondias mombin and Polyathia longifolia. Jordan Journal of Biological Sciences, 147(3427), 1-5. https://doi.org/10.12816/0027561.

Palafox-Carlos, H., Yahia, E. M., \& González-Aguilar, G. A. (2012). Identification and quantification of major phenolic compounds from mango (Mangifera indica, cv. Ataulfo) fruit by HPLC-DAD-MS/MS-ESI and their individual contribution to the antioxidant activity during ripening. Food chemistry, 135(1), 105-111. https://doi.org/10.1016/j.foodchem.2012.04.103.

Penido, A. B., De Morais, S. M., Ribeiro, A. B., Alves, D. R., Rodrigues, A. L. M., Dos Santos, L. H., \& De Menezes, J. E. S. A. (2017). Medicinal plants from northeastern Brazil against Alzheimer's disease. Evidence-Based Complementary and Alternative Medicine. https://doi.org/10.1155/2017/1753673.

Pettersen, E. F., Goddard, T. D., Huang, C. C., Couch, G. S., Greenblatt, D. M., Meng, E. C., \& Ferrin, T. E. (2004). UCSF Chimera-a visualization system for exploratory research and analysis. Journal of computational chemistry, 25(13), 1605-1612. https://doi.org/10.1002/jcc.20084.

Rahimmalek, M., Afshari, M., Sarfaraz, D., \& Miroliaei, M. (2020). Using HPLC and multivariate analyses to investigate variations in the polyphenolic compounds as well as antioxidant and antiglycative activities of some Lamiaceae species native to Iran. Industrial Crops and Products, 154 (112640), 1-9. https://doi.org/10.1016/j.indcrop.2020.112640.

Rodrigues, F. C., Santos, A. T. L., Machado, A. J. T., Bezerra, C. F., Freitas, T. S., Coutinho, H. D. M., Morais-Braga, M. F. B., Bezerra, J. W. A., Duarte, A. E., Kamdem, J. P., Boligon, A. A., Campos, M. M. A., \& Barros, L. M. (2019). Chemical composition and anti-Candida potencial of the extracts of Tarenaya spinosa (Jacq.) Raf. (Cleomaceae). Comparative immunology, microbiology and infectious diseases, 64, 14-19. https://doi.org/10.1016/j.cimid.2019.02.005.

Sales, M. D. C., Costa, H. B., Fernandes, P. M. B., Ventura, J. A., \& Meira, D. D. (2016). Antifungal activity of plant extracts with potential to control plant pathogens in pineapple. Asian Pacific Journal of Tropical Biomedicine, 6(1), 26-31. https://doi.org/10.1016/j.apjtb.2015.09.026.

Salomon, M. B., Talla, E., Nyemb, J. N., Ngassoum, M. B., Karole, T. T. R.; \& Mahmout, Y. (2018). Comparative survey of three processes used for the extraction of total phenol content and total flavonoid content of Anacardium occidentale L. and the assessment of its antioxidant activity. African Journal of Biotechnology, 17 (40), 1265-1273. https://doi.org/10.5897/AJB2017.16294. 
Santos, G. H. F., Amaral, A., \& Silva, E. B. (2018). Antibacterial activity of irradiated extracts of Anacardium occidentale L. on multiresistant strains of Staphylococcus aureus. Applied Radiation and Isotopes, 140, 327-332. https://doi.org/10.1016/j.apradiso.2018.07.035.

Santos, C. C. D. S., Guilhon, C. C., Moreno, D. S. A., Alviano, C. S., dos Santos Estevam, C., Blank, A. F., \& Fernandes, P. D. (2018). Anti-inflammatory, antinociceptive and antioxidant properties of Schinopsis brasiliensis bark. Journal of ethnopharmacology, 213(1), 176-182. https://doi.org/10.1016/j.jep.2017.11.012.

Santos, C. C. S., Masullo, M., Cerulli, A., Mari, A., Estevam, C. D. S., Pizza, C., \& Piacente, S. (2017). Isolation of antioxidant phenolics from Schinopsis brasiliensis based on a preliminary LC-MS profiling. Phytochemistry, 140, 45-51. https://doi.org/10.1016/j.phytochem.2017.04.008.

Sampaio, T. I. D. S., Melo, N. C., Paiva, B. T. D. F., Aleluia, G. A. S., Neto, F. L. P. D. S., Silva, H. R. D., Cruz, H. K. R. A. S., Sánchez-Ortiz, B. L., PinedaPeña, E. A., Balderas, J. L., Navarrete, A., \& Carvalho, J. C. T. (2018). Leaves of Spondias mombin L. a traditional anxiolytic and antidepressant: Pharmacological evaluation on zebrafish (Danio rerio). Journal of ethnopharmacology, 224, 563-578. https://doi.org/10.1016/j.jep.2018.05.037.

Singh, R., Singh, S. K., Maharia, R. S., \& Garg, A. N. (2015). Identification of new phytoconstituents and antimicrobial activity in stem bark of Mangifera indica (L.). Journal of pharmaceutical and biomedical analysis, 105(25), 150-155. https://doi.org/10.1016/j.jpba.2014.12.010.

Singh, S. K., Tiwari, R. M., Sinha, S. K., Danta, C. C., \& Prasad, S. K. (2012). Antimicrobial evaluation of mangiferin and its synthesized analogues. Asian Pacific Journal of Tropical Biomedicine, 2(2), 884-887. https://doi.org/10.1016/S2221-1691(12)60329-3.

Silva, R. A., Liberio, S. A., Amaral, F. M., Nascimento, F. R. F., Torres, L. M. B., Neto, V. M., \& Guerra, R. N. M. (2016). Antimicrobial and antioxidant activity of Anacardium occidentale L. flowers in comparison to bark and leaves extracts. Journal of Biosciences and Medicines, 4 (04), 87-89. https://doi.org/10.4236/jbm.2016.44012.

Sousa, C. M. D. M., Silva, H. R. E., Vieira, G. M., Ayres, M. C. C., Da Costa, C. L. S., Araújo, D. S., Cavalcante, L. C. D., Barros, E. D. S., Araújo, P. B. D. M., Brandão, M. S., \& Chaves, M. H. (2007). Fenóis totais e atividade antioxidante de cinco plantas medicinais. Quim. Nova, 30(2), 351-355. https://doi.org/10.1590/S0100-40422007000200021.

Temitope, O. O., Ogunmodede, A. F., Fasusi, O. A., Thonda, A. O., \& Odufunwa, A. E. (2017). Synergistic Antibacterial and Antifungal Activities of Spondias mombin Extracts and Conventional Antibiotic and Antifungal Agents on Selected Clinical Microorganisms. Scholars Journal of Applied Medical Sciences (SJAMS), 5, (2A), 307-318. https://doi.org/10.21276/sjams.2017.5.2.

Torres, C. A., Zamora, C. M. P., Nuñez, M. B., \& Gonzalez, A. M. (2018). In vitro antioxidant, antilipoxygenase and antimicrobial activities of extracts from seven climbing plants belonging to the Bignoniaceae. Journal of integrative medicine, 16(4), 255-262. https://doi.org/10.1016/j.joim.2018.04.009.

Trott, O., \& Olson, A. J. (2010). AutoDock Vina: improving the speed and accuracy of docking with a new scoring function, efficient optimization, and multithreading. Journal of computational chemistry, 31(2), 455-461. https://doi.org/10.1002/jcc.21334.

Yepez, B., Espinosa, M., López, S., \& Bolaños, G. (2002). Producing antioxidant fractions from herbaceous matrices by supercritical fluid extraction. Fluid Phase Equilibria, 194(30), 879-884. https://doi.org/10.1016/S0378-3812(01)00707-5.

Yun, J., Lee, H., Ko, H. J., Woo, E. R., \& Lee, D. G. (2015). Fungicidal effect of isoquercitrin via inducing membrane disturbance. Biochimica et Biophysica Acta (BBA)-Biomembranes, 1848 (2), 695-701. https://doi.org/10.1016/j.bbamem.2014.11.019.

Yusuf, D., Davis, A. M., Kleywegt, G. J., \& Schmitt, S. (2008). An alternative method for the evaluation of docking performance: RSR vs RMSD. Journal of chemical information and modeling, 48(7), 1411-1422. https://doi.org/10.1021/ci800084x.

Ziani, B. E. C., Carocho, M., Abreu, R. M. V., Bachari, K., Alves, M. J., Calhelha, R. C., Talhi, O., Barros, L., \& Ferreira, I. C. F. R. (2020). Phenolic profiling, biological activities and In silico studies of Acacia tortilis (Forssk.) Hayne ssp. raddiana extracts. Food Bioscience, 36 , 100616. https://doi.org/10.1016/j.fbio.2020.100616 